\title{
Variety
Trials
}

\section{Performance of Fresh-market Cabbage Hybrids during the Cool Season in a Subtropical Region}

\author{
J. Pablo Morales-Payan ${ }^{1}$ and \\ William M. Stall
}

Summary. A field study was conducted in the Constanza Valley [1234 m (4048.6 ft) above sea level, loam soil, average temperature 14.7 to 25.0 ${ }^{\circ} \mathrm{C}\left(58.46\right.$ to $\left.77.00{ }^{\circ} \mathrm{F}\right)$, photoperiod 11.2 to 12.6 hours] in the Dominican Republic, to compare the head characteristics, damage caused by diamondback moth larvae (Plutella xylostella), yield, and earliness of cabbage (Brassica olevacea Group Capitata) hybrids 'Bravo', 'Blue Vantage', 'Express', 'Genesis', 'Green Cup', 'Head Start', SW 2007, 'Hildur' (SW 2008), 'Gretania' (SW 2010), 'Hampus' (SW 2011), and XPH 847, to the

University of Florida. Horticultural Sciences Department. Gainesville, FL 110690.

This research was supported by the Florida Agricultural Experiment Station, and approved for publication as journal series R-09232. The authors appreciate the assistance received from the Duran and Quezada families, for allowing the study to be conducted on their farm Our gratitude to Dr. John Cornell, (Department of Statistics, University of Florida), for his statistical advise in the analysis of the data. Our appreciation to the seed companies Svalöf-Weibull, Asgrow Seeds, Sunseeds, Sakata Seed, Harris Moran, and Syngenta, for providing seed and information of the cultivars. Thanks to Dr. Lena Ekelund (Swedish University of Agriculture) and Dr. Gabriele Engqvist (Svalöf-Weibull, Sweden) for their personal communications about Swedish cabbage cultivars.

${ }^{1}$ Corresponding author, e-mail josepablomorales@ yahoo.com. industry standard 'Izalco'. 'Genesis' had the highest yield among all the hybrids tested, including 'Izalco'. The yield of 'Izalco' did not significantly differ from the yield of 'Blue Vantage', 'Green Cup', 'Express', XPH 847, SW 2007, and 'Bravo'. However, 'Bravo' and 'Express' were more damaged by diamondback moth larvae. 'Head Start', XPH 847, SW 2007, 'Gretania', 'Hildur', and 'Hampus' were either significantly less productive or more susceptible to damage by the diamondback moth larvae than 'Izalco'. In terms of yield, earliness, head shape, and losses due to the diamondback moth larvae, 'Green Cup', 'Blue Vantage' and 'Genesis' were comparable or superior to 'Izalco'.

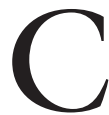
abbage is a vegetable crop of global importance. In 2002, about 3 million ha $(7.4$ million acres) of cabbage were harvested in the world. The leading countries for cabbage production in 2002 were China, India, Russia, U.S., and Indonesia [Food and Agriculture Organization of the United Nations (FAO), 2003]. In the U.S., about 104,000 ha $(256,980$ acres) were planted with cabbage (fresh and processing market) in 2002 (FAO, $2003)$. About 31,190 ha $(77,069$ acres) of fresh-market cabbage were harvested in the U.S. in 2002, with a value in excess of $\$ 301$ million. The leading states in cabbage production in 2002 were California, New York, Texas, North Carolina, Florida, and Georgia (USDA, 2003).

Cabbage is also one of the most important vegetable crops in the Dominican Republic (DR). The DR is located in the Caribbean Sea, between lat. $17^{\circ} 36^{\prime}$ and $19^{\circ} 31^{\prime} \mathrm{N}$, and long. 69 $19^{\circ}$ and $72^{\circ} 3 \mathrm{I}^{\prime} \mathrm{W}$. The DR lowlands (near sea level) have a tropical climate averaging about $26^{\circ} \mathrm{C}\left(78.8^{\circ} \mathrm{F}\right)$ throughout the year. The Constanza Valley, located at an altitude of $1234 \mathrm{~m}$ above sea level has lower temperatures [annual average about $\left.18{ }^{\circ} \mathrm{C}\left(64.4{ }^{\circ} \mathrm{F}\right)\right]$, and is the country's main production area for cabbage and other cool weather vegetables.

In the DR, cabbage is consumed mostly as a fresh salad. Local consumers prefer compact, round to tall, medium size cabbage heads 15 to $20 \mathrm{~cm}(5.9$ to 7.9 inches) in diameter and $>1.5 \mathrm{~kg}$ (3.31 lb). Heads weighing less than $1 \mathrm{~kg}(2.2 \mathrm{lb})$ are seldom marketable. About 2050 ha (5065.5 acres) have been identified as adequate for commercial cabbage production using current production systems [Secretaría de Estado de Agricultura (SEA), 1999). In 2002, the area under commercial cabbage production reached about 800 ha (1976.8 acres) (SEA, 2003).

Because of the proven reliability of old cultivars and the limited offer of new superior cultivars, growers have had a tendency to use the same genetic material for nearly a decade. As a result, cabbage growers have overwhelmingly used one or two cultivars at any given time. In the 1970s, the cabbage market was dominated by 'Hit' in the lowlands (Montás, 1980), and 'Marion Market' and 'Copenhagen Market' in the highland valleys. In the 1980s, 'Fortuna' was the leading cultivar (Sarita, 1993), while in the 1990s the main cultivar was 'Izalco' (Rodríguez, 2000).

The larval stage of the diamondback moth (DBM), which perforates the cabbage head, is the worst arthropod pest and the main biological limitation for cabbage production in the DR. Uncontrolled attacks of DBM commonly cause total yield loss, and deficient management of this pest have been known to result in $>30 \%$ marketable yield loss (Schmutterer, 1990). Management of DBM in the DR usually involves scouting and application of low risk insecticides (azadirachtin, Bacillus thuringiensis) in the early growth stages of the crop. However, as the season progresses, weekly applications of various insecticides are usually required to suppress the pest sufficiently to maintain marketable yield loss below $10 \%$. In extreme cases, two or three insecticide applications per week have been necessary to control DBM populations (Torres-Mejía, 1994). As a result, DBM populations resistant to insecticides develop, dictating a continuous substitution of active in- 
gredients for their control. The frequent use and abuse of insecticides for DBM control has been deemed potentially dangerous for consumers, as well as ecologically unsustainable. Although no DBM-resistant cultivars of cabbage are known, differential preference of DBM for cabbage cultivars has been reported (Talekar and Shelton, 1993). Cultivars less prone to be attacked by DBM should sustain less damage and require less intensive insecticide application programs. Therefore, it would be advantageous for growers to use such cabbage cultivars.

In any crop, the genetic uniformity represented by a vastly predominant cultivar is an intrinsically perilous situation in terms of pest and disease susceptibility. In a given crop, growers should be supplied with unbiased information regarding the potential of newly introduced cultivars as compared to established materials. When comparing cabbage cultivars, head characteristics and damage caused by DMB are essential variables. Little unbiased experimental information is available regarding the comparative performance of newly introduced cultivars in the Caribbean basin. The objectives of this study were to compare the yield, head characteristics, and damage by DBM of 11 cabbage hybrid cultivars to the industry standard 'Izalco' in the Constanza Valley, and to provide growers with unbiased information to enable them to select alternative cultivars to 'Izalco'.

\section{Materials and methods}

Trials were established in a grower's field in the Constanza Valley, DR, during January to April and February to May 1994. The treatments were the hybrid cultivars SW 2007, SW 2008 (later named 'Hildur'), SW 2010 (later named 'Gretania'), SW 2011 (later named 'Hampus') (Svalöf-Weibull. Svalöv, Sweden), 'Green Cup', 'Express', 'Head Start', XPH 847 (Asgrow Seeds. Oxnard, Calif.), 'Genesis' (Sunseeds. Parma, Idaho, U.S.), 'Blue Vantage' (Sakata Seed. Kanagawa, Japan), 'Bravo' (Harris Moran. Modesto, Calif.), and the industry standard 'Izalco' (Syngenta. Boise, Idaho). The mean temperature in that period was $17.2{ }^{\circ} \mathrm{C}\left(62.96{ }^{\circ} \mathrm{F}\right)$. Maximum and minimum temperatures averaged about 25.0 and $14.7^{\circ} \mathrm{C}$, respectively, near the general optimum values for cabbage production. The photoperiod ranged from $11.2 \mathrm{~h}$ in January to $12.8 \mathrm{~h}$ in May. Wind speed in the location during those months averaged $10.5 \mathrm{~km} \cdot \mathrm{h}^{-1}$ $(6.52 \mathrm{miles} / \mathrm{h})$. Precipitation was about $80 \mathrm{~mm}$ (3.15 inches) during each crop season. Mean relative humidity during the study was $77 \%$.

The experiments were established in a loamy soil (Typic Hapludolls), with $2.8 \%$ organic matter, $\mathrm{pH} 7.4$, and electrical conductivity of $0.2 \mathrm{mmhos} \cdot \mathrm{cm}^{-1}$. The soil contained $70 \mathrm{mg} \cdot \mathrm{kg}^{-1}(\mathrm{ppm})$ of extractable phosphorus $(\mathrm{P}), 2$ meq per $100 \mathrm{~g}(3.53 \mathrm{oz})$ of soil of potassium $(\mathrm{K}), 24 \mathrm{meq}$ of calcium $(\mathrm{Ca}), 8$ meq of magnesium $(\mathrm{Mg}), 3.2 \mathrm{mg} \cdot \mathrm{kg}^{-1}$ of iron $(\mathrm{Fe}), 2.8 \mathrm{mg} \cdot \mathrm{kg}^{-1}$ of manganese (Mn), $2.6 \mathrm{mg} \cdot \mathrm{kg}^{-1}$ of copper $(\mathrm{Cu}), 3.0$ $\mathrm{mg} \cdot \mathrm{kg}^{-1}$ of zinc $(\mathrm{Zn})$, and $0.7 \mathrm{mg} \cdot \mathrm{kg}^{-1}$ of boron (B). Olsen's method (Olsen and Sommers, 1982) was used to determine extractable $P$, whereas exchangeable $\mathrm{K}, \mathrm{Ca}$, and $\mathrm{Mg}$ were determined using the ammonium acetate extraction method (Thomas, 1982). Extractable micronutrients were determined using the diethylenetriaminepentaacetic acid (DTPA) method (Lindsay and Norvell, 1978). B was extracted using the saturated paste method (Gupta et al., 1985).

The soil was fertilized $2 \mathrm{~d}$ before bed formation, with a broadcast application of $15 \mathrm{~N}-6.6 \mathrm{P}-12.5 \mathrm{~K}$ at the rate of $1100 \mathrm{~kg} \cdot \mathrm{ha}^{-1}(981.4 \mathrm{lb} / \mathrm{acre})$, as recommended for the location. Cabbage transplants [ three or four true-leaf stage, about $10 \mathrm{~cm}$ (3.9 inches) tall] were planted $0.4 \mathrm{~m}$ ( 15.75 inches $)$ apart in single rows on a $0.7-\mathrm{m}$ (27.56-inch) spacing. Overhead irrigation was used as required, typically every five days, to bring the soil moisture near field capacity. Values for micronutrient availability in the soil were considered low for cabbage (Sarita, 1993), thus a commercial foliar fertilizer (11N$3.52 \mathrm{P}-4.24 \mathrm{~K}-0.3 \mathrm{Ca}-0.3 \mathrm{Mg}-0.23 \mathrm{~S}-$ $0.10 \mathrm{Fe}-0.05 \mathrm{Cu}-0.05 \mathrm{Mn}-0.05 \mathrm{Zn}-$ 0.02B) (Bayer Dominicana. Santo Domingo, Dominican Republic) was applied two times (20 and $35 \mathrm{~d}$ after transplanting) at the rate of $2.0 \mathrm{~L} \cdot \mathrm{ha}^{-1}$ (0.21 gal/acre).

Pesticide application was made according to local recommendations (Sarita, 1993). Insecticides for DMB control were applied once per week at recommended label rates. The insecticide sequence of permethrin, methamidophos, imidacloprid, endosulfan, methomyl, and acephate was used. Every $10 \mathrm{~d}$ a fungicide was applied (cupric hydroxide alternated with chlorothalonil or iprodione) to control commonly occurring diseases such as alternaria leaf spot (Alternaria spp.) and black rot (Xanthomonas campestris). No chemical herbicides were used, and weeds were hoed every 10 $\mathrm{d}$. According to the system proposed by Osborne and Simonne (2002) to rate overall growing conditions in cultivar experiments (soil, weather, fertilization, and irrigation), the conditions for cabbage production during this study were good to very good.

The treatments (cultivars) were established in a complete randomized block design with five replications. Experimental units consisted of two rows containing 14 plants each, as recommended by Maynard (1987). Cabbage heads were harvested when they had reached their apparent maximum size and firmness, and showed a glossy sheen appearance typical of commercial maturity. Two plants at the end of each row were used as guard plants. At harvest, 20 plants per plot were evaluated for earliness, yield, damage by DBM, and head characteristics (average head weight, height and diameter, core length and diameter).

Earliness was determined by counting the days from transplanting to first harvest $(>70 \%$ of the heads reached commercial maturity). Yield, average weight, diameter, and height of the heads were determined at harvest, keeping three or four wrapper leaves. Shortly after harvest, six heads per plot were cut longitudinally in the middle, to determine their core length and base diameter.

The extent of damage caused by DBM was rated visually immediately after harvest, using a 1 to 6 scale proposed by Chalfant and Brett (1967) and used in other studies involving DBM damage (Chalfant et al., 1979; Greene et al., 1969; Hines and Hutchinson, 2001; Workman et al., 1980), where 1 $=$ no apparent insect damage, $2=$ minor insect feeding on wrapper or outer leaves $(<2 \%$ leaf area eaten) and no damage to the head, $3=$ moderate insect feeding on wrapper or outer leaves ( $2 \%$ to $5 \%$ leaf area eaten) and no damage to the head, $4=$ feeding on wrapper or outer leaves ( $6 \%$ to $10 \%$ leaf area eaten) and minor damage to the head, $5=$ moderate to heavy feeding ( $11 \%$ to $30 \%$ leaf area eaten) on wrapper and head leaves, with moderate feeding damage to the head, and $6=$ considerable insect feeding on wrapper leaves $(>30 \%$ leaf area 
eaten), with major damage to the head, with numerous feeding scars. Cabbage heads with DBM damage of 4 to 6 were considered unmarketable.

A sensory evaluation was conducted using five heads per plot. Flavor, texture, and appearance were evaluated within 48 h after harvest. Volunteer university students, farm crew workers, and housewives, were presented individually with coded blind samples of the cultivars. The panelists consumed fresh shredded cabbage with salt, vinegar, and olive oil dressing. A standard hedonic scale of 1 to 9 was used to rate the cultivars, where $1=$ completely unacceptable, 2 = strongly dislike, 3 = somewhat dislike, $4=$ dislike, $5=$ indifferent, $6=$ acceptable, $7=$ good, $8=$ very good, $9=$ excellent.

Data were analyzed for normality plotting residuals and with the Shapiro-Wilk, Martínez-Iglewickz, and D'Agostino omnibus tests, using the procedures in the softwares NCSS and PASS (Hintze, 2001). Those tests revealed the data conformed to normality ( $5 \%$ probability level) and analysis of variance (ANOVA) could be performed for all the variables, except for damage caused by DBM and yield of heads unmarketable due to DBM damage, which did not follow a normal distribution and were analyzed using Friedman's test of ranks (Table 1 ).

\section{Results and discussion}

Interactions between trials and cultivars were not significant. Hence, data were pooled over trials.
Earliness is a desirable trait in cabbage. The earliest cultivars were 'Head Start' and 'Express', which were ready to harvest between 70 and $75 \mathrm{~d}$ after transplanting (DAT), 2 to 3 weeks earlier than the latest cultivars ('Hildur' and 'Hampus', harvested 90 DAT), and 1 week earlier than the standard 'Izalco'. The other cultivars were intermediate in their earliness, being ready to harvest between 75 and 85 DAT (Table 2).

'Genesis' had the highest marketable yield, about 15\% higher than 'Bravo', 'Blue Vantage', and the standard 'Izalco' (Table 2). The lowest yielding cultivars were 'Hampus', 'Hildur', and 'Gretania', which had marketable yields of about 30\%, $45 \%$, and $49 \%$ as compared to the yield of 'Genesis', and $<65 \%$ as compared to 'Izalco' (Table 2). The late harvesting time and low yields obtained with 'Hildur', 'Gretania', and 'Hampus' may be partially due to the fact that those cultivars were bred in Sweden, where the cabbage growing season is usually longer, colder, and with longer photoperiods than the cool season in the subtropics.

All cultivars were affected by DBM attack, but the damage significantly differed between cultivars (Table 2). 'Express', SW 2007, 'Gretania', and 'Head Start', were among the cultivars most damaged by DBM, with damage ratings between 2 and 3. 'Hildur', 'Hampus', 'Green Cup', 'Izalco', and 'Genesis' were among the cultivars least damaged by DBM.
The damage caused by DBM did not exceed an average rating of 3 in any of the cultivars. Heads with average DBM damage of 3 to 4 are usually considered marginally marketable, whereas heads with damage $>4$ are usually not marketable for fresh consumption. Therefore, there was marketable yield in all the cultivars. However, differences in the extent of damage and the percentage of heads rendered unmarketable by DBM suggested that DBM preferred some cultivars to others (Table 2 ).

The yield loss due to DBM damage (which otherwise would have been marketable) varied between cultivars and was not proportional to the total yield of a given cultivars (Table 2 ). Thus, the cultivars not only had different yields, but also were differentially affected by DBM. In 'Express' and SW 2007, the yield made unmarketable by DBM attack was significantly higher than that of 'Green Cup', SW 2011, 'Gretania', 'Genesis', 'Izalco', 'Bravo', and 'Blue Vantage'. Over $20 \%$ of the total yield of 'Express', 'Head Start', and SW 2007 was lost due to DBM damage (Table 2). The lower tolerance of 'Head Start' and 'Express' to DBM may be related to their more rapid growth (and earliness), which would likely maintain a large portion of the plant in a more succulent stage, and make them more attractive to DBM than cultivars with a slower growth rate.

In all the cultivars, the incidence of DBM larvae and the extent of their damage exceeded the action thresholds

Table 1. Summary of normality tests and analysis of variance for earliness, head characteristics, diamondback moth (DBM) damage, and yield of 12 cabbage cultivars grown during the cool season [ 14.7 to $25.0{ }^{\circ} \mathrm{C}\left(58.46\right.$ to $\left.77.00{ }^{\circ} \mathrm{F}\right)$ in $^{\mathrm{Constan}}$ za, Dominican Republic. ${ }^{z}$

\begin{tabular}{|c|c|c|c|c|c|}
\hline Variable & Normality $^{\mathrm{y}}$ & $\begin{array}{c}\text { Mean } \\
\text { square } \\
\text { of error }\end{array}$ & $\begin{array}{c}\mathrm{F} \\
\text { ratio }\end{array}$ & $\begin{array}{c}\text { Significance } \\
(\text { alpha }=0.05)\end{array}$ & $\begin{array}{c}\text { Coefficient } \\
\text { of variation } \\
(\%)\end{array}$ \\
\hline Marketable yield & Yes & 24.94 & 40.31 & * & 28.8 \\
\hline DBM damage & $\mathrm{No}^{x}$ & 0.06 & 11.06 & * & $\mathrm{NA}^{\mathrm{v}}$ \\
\hline Yield loss due to DBM damage & $\mathrm{No}^{\mathrm{x}}$ & 1.60 & 80.31 & * & $\mathrm{NA}^{\mathrm{v}}$ \\
\hline Head weight & Yes & 0.02 & 40.95 & * & 28.3 \\
\hline Core diameter & Yes & 0.04 & 13.75 & * & 15.3 \\
\hline Core length & Yes & 0.16 & 15.0 & * & 11.2 \\
\hline Appearance & Yes & 0.04 & 18.24 & * & 5.4 \\
\hline Flavor & Yes & 0.04 & 21.97 & * & 5.3 \\
\hline Texture & Yes & 0.07 & 8.43 & * & 5.7 \\
\hline
\end{tabular}

${ }^{2}$ Values are the pooled results of two separate experiments.

y'Agostino omnibus, Martínez-Iglewicz, and Shapiro-Wilk tests (Hintze, 2001).

${ }^{x}$ Friedman's test of ranks (alpha 5\%) was conducted on variables not conforming to normality (Hintze, 2001).

${ }^{\mathrm{N} A}=$ not applicable.

*Significant. 
Table 2. Earliness, marketable yield, and diamondback moth (DBM) damage in 12 cabbage cultivars grown during the cool season $\left(14.7\right.$ to $25.0^{\circ} \mathrm{C}, \mathbf{5 8 . 4 6}$ to $77.00^{\circ} \mathrm{F}$ ) in Constanza, Dominican Republic. ${ }^{\mathrm{z}}$

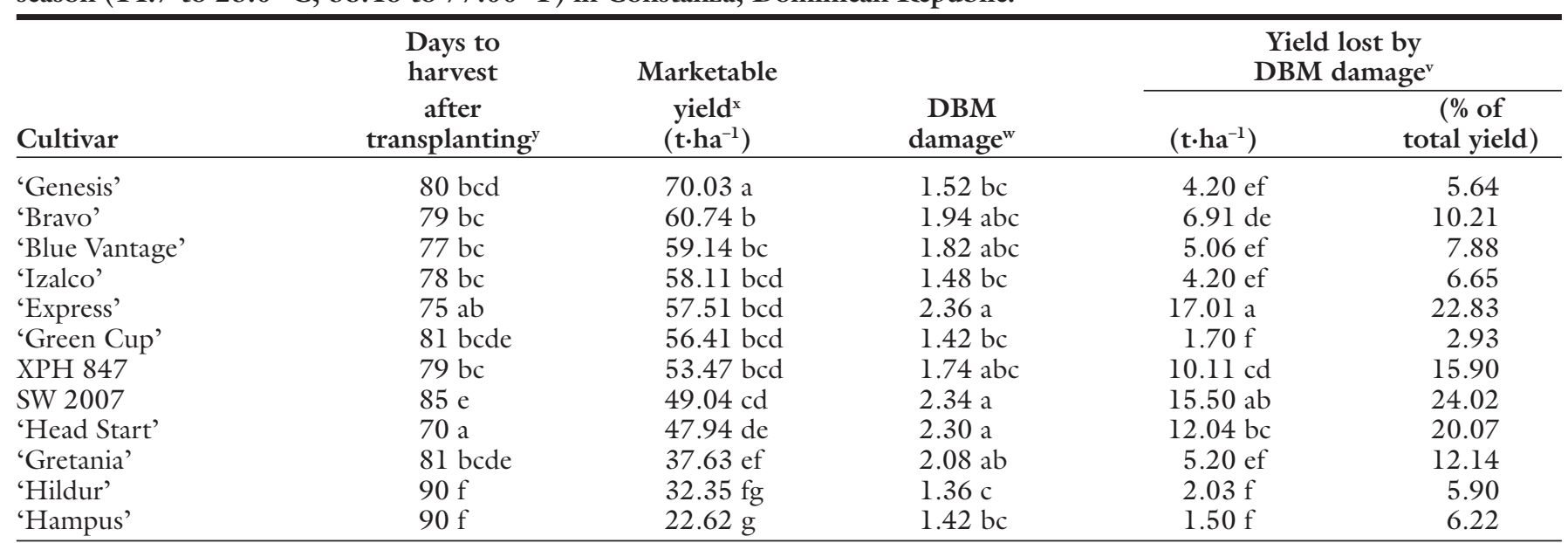

${ }^{2}$ Values are the pooled results of two separate experiments.

Within the same column, values followed by the same letter are not significantly different, according to Tukey-Kramer's multiple comparison test (alpha 5\%).

${ }^{\mathrm{x}} \mathrm{l} .0 \mathrm{t} \cdot \mathrm{ha}^{-1}=8.92 \mathrm{cwt} /$ acre

"On a standard 1 to 6 scale for DBM damage, where $1=$ no damage, $6=$ extensive damage and no marketable head.

"Values followed by the same letter are not significantly different, according to Friedman's test of ranks (alpha 5\%).

of one or two new holes per head, or new window (damage caused by larvae feeding on the leaf tissue without rupturing the upper epidermis) per head, or up to $10 \%$ plants with new damage (data not shown), proposed by Chalfant et al. (1979), Workman et al. (1980), and Leibee et al. (1984), respectively. Therefore, weekly applications of insecticides to suppress DBM were justified. Nevertheless, several cultivars were less damaged by DBM than others (Table 2), which may be interpreted as an expression of cultivar preference by the pest, possibly associated with the smell, taste and/or texture of each cultivar. In practical terms, this finding could imply that to reduce the extent of marketable losses inflicted by DBM on the least tolerant cultivars, more frequent applications of insecticides and/or stronger active ingredients should be used to suppress DBM. Those options may be neither economical nor ecologically acceptable. Thus, cultivars less attractive to DBM would be more suitable for sustainable production systems. The importance of DBM in cole crops is heightened by the fact that cultivars of cabbage, broccoli (Brassica oleracea group botrytis) and chinese cabbage (B. pekinensis) have been molecularly transformed to express toxins (Crylc) of Bacillus thuringiensis that kill DBM larvae, but DBM populations resistant to those toxins have already developed (Cho et al., 2001; Schuler and van Em- den, 2000; Zhao et al., 2001).

Naturally occurring differential tolerance to DMB in cabbage cultivars has been previously reported in the DR and elsewhere. Abro and Wright (1989) screened large numbers of cabbage cultivars in Europe and found that DBM damaged them to different extents. In England, Schuler and van Emden (2000) reported that cultivar 'Red Drumhead' was less affected by DBM than 'Minicole', whereas 'Aquarius' and 'Offenham 2' were more susceptible. Navarro and Misa (1985) reported that in humid tropical lowlands of American Samoa, 'Jubilee' was completely destroyed by DBM, but 'Tropic Drum', 'Tropic Globe', and 'County Green' were significantly

Table 3. Head characteristics of 12 cabbage cultivars grown during the cool season $\left(14.7\right.$ to $25.0{ }^{\circ} \mathrm{C}, 58.46$ to $77.00{ }^{\circ} \mathrm{F}$ in Constanza, Dominican Republic . ${ }^{\mathrm{z}}$

\begin{tabular}{|c|c|c|c|c|c|}
\hline Cultivar & $\begin{array}{c}\text { Head } \\
\text { wt } \\
(\mathrm{kg})^{\mathrm{y}, \mathrm{x}}\end{array}$ & $\begin{array}{l}\text { Head } \\
\text { diam } \\
(\mathrm{cm})^{\mathrm{w}}\end{array}$ & $\begin{array}{c}\text { Head } \\
\text { length } \\
(\mathrm{cm})\end{array}$ & $\begin{array}{l}\text { Core } \\
\text { diam } \\
(\mathrm{cm})\end{array}$ & $\begin{array}{c}\text { Core } \\
\text { length } \\
(\mathrm{cm})\end{array}$ \\
\hline 'Genesis' & $2.34 \mathrm{a}$ & $15.37 \mathrm{a}$ & $15.06 \mathrm{c}$ & $3.17 \mathrm{ab}$ & $7.38 \mathrm{a}$ \\
\hline 'Blue Vantage' & $1.83 \mathrm{bc}$ & $15.94 \mathrm{a}$ & $15.96 \mathrm{a}$ & $3.25 \mathrm{ab}$ & $7.54 \mathrm{a}$ \\
\hline 'Izalco' & $1.82 \mathrm{bc}$ & $15.70 \mathrm{a}$ & $15.46 \mathrm{~b}$ & $3.33 \mathrm{a}$ & $7.40 \mathrm{a}$ \\
\hline 'Express' & $1.80 \mathrm{bc}$ & $15.18 \mathrm{a}$ & $14.42 \mathrm{~d}$ & $3.16 \mathrm{ab}$ & $7.18 \mathrm{ab}$ \\
\hline SW 2007 & $1.53 \mathrm{~cd}$ & $12.50 \mathrm{~cd}$ & $14.18 \mathrm{~d}$ & 2.90 bcde & $6.41 \mathrm{bc}$ \\
\hline 'Head Start' & $1.50 \mathrm{~cd}$ & $14.14 \mathrm{~b}$ & $13.24 \mathrm{e}$ & $2.67 \mathrm{cdef}$ & $5.82 c$ \\
\hline 'Gretania' & $1.19 \mathrm{de}$ & $13.24 \mathrm{c}$ & $12.36 \mathrm{f}$ & $2.48 \mathrm{ef}$ & $6.04 \mathrm{c}$ \\
\hline 'Hildur' & $1.02 \mathrm{ef}$ & $12.72 \mathrm{~cd}$ & $14.28 \mathrm{~d}$ & $2.60 \mathrm{def}$ & $7.31 \mathrm{ab}$ \\
\hline 'Hampus' & $0.72 \mathrm{f}$ & $11.90 \mathrm{~d}$ & $12.98 \mathrm{e}$ & $3.00 \mathrm{abcd}$ & $6.48 \mathrm{bc}$ \\
\hline
\end{tabular}

${ }^{2}$ Values are the pooled results of two separate experiments.

yithin a column, values followed by the same letter are not significantly different, according to the Tukey-Kramer's multiple comparison test (alpha $5 \%$ ).

${ }^{x} 1.0 \mathrm{~kg}=2.20 \mathrm{lb}$.

${ }^{\mathrm{w}} 1.0 \mathrm{~cm}=0.39$ inches. 
less affected. In the DR, cultivar 'Constanza' was less susceptible to DMB damage, apparently due to its coarser texture. However, the same attribute made 'Constanza' less appealing to consumers as well.

In fresh-market cabbage, head size, shape and weight are important attributes, although consumer preferences vary between regions. Heads of 'Genesis' averaged $2.3 \mathrm{~kg}(5.07 \mathrm{lb})$, significantly higher than all the other cultivars tested, and about $25 \%$ higher than 'Izalco', 'Bravo', 'Blue Vantage', and 'Express' (Table 3). That finding may partially explain the higher yields of 'Genesis'. The average head weight of 'Genesis' was nearly $50 \%$ above the minimum marketable weight of $1.5 \mathrm{~kg}$. Since oversized heads usually reach a higher price per unit weight, 'Genesis' would likely increase revenues for growers. 'Blue Vantage', 'Express', 'Green Cup', XPH 847, and 'Bravo' average head weights were not statistically different than that of the standard cultivar 'Izalco'. Those cultivars, along with SW 2007 and 'Head Start' were also above the $1.5 \mathrm{~kg}$ per head grade. 'Green Cup', XPH 847, SW 2007, and 'Head Start' weighed between 1.5 and $1.7 \mathrm{~kg}(3.75 \mathrm{lb})$ per head, considered to be acceptable weights for local market standards. The average head weights of 'Gretania', 'Hildur', and 'Hampus' were lower than those of 'Izalco', and below local marketable standards for fresh cabbage (Table 3 ).

'Izalco', 'Bravo', 'Blue Vantage', and 'Express' measured about $15 \mathrm{~cm}$ in diameter, being the widest among all the cultivars. The smallest head diameter was found in 'Hampus', about $12 \mathrm{~cm}$ (4.7 inches) (Table 3 ). While a large head diameter usually is a desirable trait, consumers also pay attention to its relation to head vertical length or height, which defines the head shape. 'Genesis' and 'Bravo' had head lengths of about $15 \mathrm{~cm}$, the same as 'Izalco', making them nearly round $(15 \times 15 \mathrm{~cm})$. Heads of XPH 847 were also nearly round, but smaller [ 12.5 $\times 12.5 \mathrm{~cm}$ (4.92 inches)]. Heads of 'Bravo' were flatter ( $10 \mathrm{~cm}$ in length) relative to 'Izalco', making 'Bravo' less attractive to DR markets. Similarly, the heads of 'Head Start', 'Express', and 'Gretania' had a shorter length than diameter, making them somewhat flatter than those of 'Izalco'. 'Green Cup', SW 2007, 'Hampus', and 'Hildur' had heads with diameters smaller than their vertical lengths, which for DR markets is more attractive than flat heads. Large core lengths and diameters are undesirable in fresh cabbage cultivars. In general, cultivars with larger head diameters also had larger core diameters. Similarly, larger head lengths were usually associated with larger core lengths (Table 3). For most cultivars, core diameters and lengths measured about $20 \%$ to $50 \%$ of those variables in the heads. However, in 'Bravo' core length was about $73 \%$ of the head length.

Panelist ratings for appearance and flavor of shredded cabbage were similar for each given cultivar. 'Green Cup', 'Blue Vantage', 'Express', 'Izalco' and $\mathrm{XPH} 847$ rated $>8.5$ (very good to excellent) for appearance and flavor, being significantly superior to 'Bravo', 'Head Start', and 'Genesis', which were rated about 8 (very good). Other cultivars were rated 7 to 8 (good to very good). For texture, 'Express', SW 2007, 'Gretania', and 'Head Start' were rated significantly more tender (>8.5) than the other cultivars, which were rated 7.5 to 8.2 (good to very good) (data not shown). Overall, sensory evaluations indicated that all the cultivars would at least be rated good ( 7 in our scale), although 'Express' was among the highest ranking cultivars for appearance, flavor, and texture, exceeding 'Izalco' in the texture test.

The selection of a cultivar for a determined region or market should be based on the overall performance of the cultivar in the specific region (or a similar one), local production limitations, and local consumer preferences. For example, 'Gretania' was developed as a summer cabbage for northern Europe, with the desirable attributes of extended holding in the field without cracking and a long outer stem to make it easier to harvest $(\mathrm{G}$. Engqvist, personal communication). Under the conditions of this study, 'Gretania' had lower yields and had more damage from DBM than 'Izalco', showing that it would likely be unsuitable for commercial production under our conditions. SW 2007, also bred in northern Europe, performed better than 'Hildur' in this study. Several of the cultivars tested, such as 'Blue Vantage', 'Bravo', 'Izalco', and 'Head Start', have shown good performance in field trials, are currently recommended for commercial production, and/or are considered industry standards in major cabbage production regions in the $\mathrm{DR}$ (Canela, 1992), Central America (Araya et al, 1999), and the U.S. (Dainello and Cotner, 2001; Kelley and Hall, 1998; Kleinhenz et al., 2001; Mayberry et al., 2000; Maynard et al., 2001; Orzolek et al., 2000; Reiners et al., 2002; Strang et al., 1999).

In studies comparing cabbage cultivars, the highest yielding cultivars have not always been the best overall cultivars (Orzolek et al., 2000). Jones (1999) reported that in studies conducted in Kentucky 'Bravo' attained the highest yields and showed good disease resistance, but the heads were considered to have low density (not firm enough) for local markets. In Ohio, 'Blue Vantage' was a good yielder, but the heads were deemed too flat (Scaife et al., 1998).

In our study, cultivars 'Bravo', 'Blue Vantage', 'Green Cup', and 'Izalco' had comparable earliness, yield, DBM damage, and sensory evaluations, but 'Bravo' produced flat heads and long cores, which may reduce its acceptance. 'Genesis' was similar to 'Blue Vantage', 'Green Cup', and 'Izalco' in almost all the variables measured, but 'Genesis' significantly exceeded the yields and individual head weights of these three cultivars. 'Head Start' and 'Express' were earlier than 'Izalco', but they were also more severely damaged by DBM, had lower yields and flatter heads than the standard 'Izalco'. 'Express', 'Head Start', SW 2007, and 'Gretania' were among the consumers' favorite because of their tenderness, but were also among the more affected by DBM, maybe for the same reason.

Most cabbage cultivars are developed for production in cool weather, and thus the optimum temperatures for their production are 16 to 18 ${ }^{\circ} \mathrm{C}\left(60.8\right.$ to $\left.64.4{ }^{\circ} \mathrm{F}\right)$, and dry matter concentration and yield of most cultivars tend to decrease as average temperatures increase from 20 to $25{ }^{\circ} \mathrm{C}\left(68.0\right.$ to $\left.77.0{ }^{\circ} \mathrm{F}\right)$ (Hara and Sonoda, 1982; Sundstrom and Story, 1984). Temperature conditions during the cabbage-growing season in most major cabbage regions are within the physiological optimal for the crop. During our study, weather conditions were adequate for cabbage production. Thus, these results may be applicable not only to the cool season of subtropical regions, but also to 
other regions with similar weather during their cabbage season. Differences in soils, photoperiod, pest and disease pressure, and other aspects of the natural environment and the crop management system may affect cultivars in different ways, conferring some cultivars a performance advantage over others. Overall and taking into account earliness, yield, head shape, and losses due to DBM, under conditions similar to those of this study, hybrids 'Genesis', 'Blue Vantage', and 'Green Cup' could be considered comparable or superior to 'Izalco'.

\section{Literature Cited}

Abro, G.H. and D.J. Wright. 1989. Host plant preference and the influence of different cabbage cultivars on the toxicity of abamectin and cypermethrin against Plutella xylostella (Lepidoptera: Plutellidae). Ann. Appl. Biol. 115:481-487.

Araya, L., L.A. Monge, E. Carrazo, and V.M. Cartín. 1999. Diagnóstico del uso de insecticidas para el combate de Plutellaxylostella en Costa Rica. Manejo Integrado de Plagas 52:69-73.

Canela, F. 1992. Evaluación de 14 cultivares de repollo en siembra de primavera en San Cristóbal. BS Agr. Thesis. Pedro Henríquez Ureña Natl. Univ. Santo Domingo, Dominican Republic.

Chalfant, R.B. and C.H. Brett. 1967. Interrelationship of cabbage variety, season, and insecticide control of the cabbage looper and the imported cabbage worm. J. Econ. Entomol. 60: 687-690

Chalfant, R.B., W.H. Denton, D.J. Schuster, and R.B. Workman. 1979. Management of cabbage caterpillars in Florida and Georgia by using visual damage threshold. J. Econ. Entomol. 72: 411-413.

Cho, H.S., J. Cao, J.P. Ren, and E.D. Earle. 2001. Control of lepidopteran insect pests in transgenic chinese cabbage (Brassica rapa ssp. pekinensis) transformed with a synthetic Bacillusthuringiensis crylC gene. Plant Cell Rpt. 20(1):1-7.

Dainello, F. and S. Cotner (eds.). 2001. Texas vegetable growers' handbook. Texas A\&M Univ., College Station.

Food and Agriculture Organization of the United Nations. 2003. Agricultural statistics 2002. FAO. Rome, Italy.

Greene, G.L., W.G. Genung, R.B. Workman, and E. G Klesheimer. 1969. Cabbage looper control in Florida- a cooperative program. J. Econ. Entomol. 62:798-800.

Gupta, U.C., Y.W. Jame, C.A. Campbell, A.J. Leyshon, and W. Nocholaichuk. 1985. Boron toxicity and deficiency: A review. Can. J. Soil Sci. 65:381-409.

Hara, T. and Y. Sonoda. 1982. Cabbage head development as affected by nitrogen and temperature. Soil Sci. Plant Nutr. 28:109-117.
Hines, R.L. and W.D. Hutchinson. 2001. Evaluation of action thresholds and spinosad for lepidopteran pest management in Minnesota cabbage. J. Econ. Entomol. 94(1):190-196.

Hintze, J. 2001. NCSS Statistical system for Windows. Quick start and self help manual. NCSS. Kaysville, Utah.

Jones, T. 1999. Spring fresh market/slaw cabbage cultivar evaluation in eastern Kentucky, p. 21-22. In: Brent Rowell (ed.). Univ. Kentucky. 1999 Fruit and Veg. Crops Res. Rpt. PR-423.

Kelley, W.T. and M.R. Hall. 1998. 1993 Commercial vegetable variety trials-Cabbage. Univ. Ga. Coop. Ext. Serv. Publ. H-98-045.

Kleinhenz, M.D., B. Schult, and T. Radovich. 2001. Fresh market/slaw and kraut cabbage germplasm evaluation results in 2001. Ohio State Univ. Hort. Crop Sci. Ser. 715

Leibee, G.L., R.B. Chalfant, D.J. Schuster, and R. B. Workman. 1984. Evaluation of visual damage thresholds for management of cabbage caterpillars in Florida and Georgia. J. Econ. Entomol. 77:1008-1011.

Lindsay, W.L. and W.A. Norvell. 1978. Development of a DTPA soil test for zinc, iron, manganese, and copper. Soil Sci. Soc. Amer. J. 42:421-428.

Mayberry, K.S. 2000. Sample cost to establish and produce cabbage. U. S. Coop. Ext. Imperial Valley Circ. 104-V.

Maynard, D.N., A.M. Dunlap, and B.J. Sidoti. 2001. Cabbage variety evaluation. Univ. Fla. Gulf Coast Res. Educ. Ctr. Res. Rpt. BRA2001-4.

Maynard,D.N. 1987. Vegetable variety evaluation demonstrations: A manual for county extension faculty. Univ. Fla. Inst. Food Agr. Sci. Fla. Coop. Ext. Ser. Circ. 762.

Montás, F. 1980. Producción de Repollo en Zonas Bajas. Southern Ctr. for Agr. Dev. State Secretariat of Agr. San Cristóbal, Dominican Republic.

Navarro, A.A. and M. Misa. 1985. Vegetable research reports 1983-1985. Amer. Samoa Land Grant Comm. College Tech. Rpt. 1.

Olsen, S.R. and L.E. Sommers. 1982. Phosphorus, p. 403-430. In: A.L. Page et al. (eds.). Methods of soil analysis: Part 2. Chemical and microbiological properties. Amer. Soc. Agron., Madison, Wis

Orzolek, M.D., W.J. Lamont, and L. Otjen. 2000. 1997 Spring and fall cabbage cultivar trials in Pennsylvania. HortTechnology 10(1): 218-221.

Osborne, J. and E. Simonne. 2002. Data collection and statistical topics for the preparation and review of manuscripts. HortTechnology 12(4): 567-583.

Reiners, S., C. Petzoldt, and M. Hoffmann. 2002. Integrated crop and pest management guidelines for commercial vegetable production. Cornell Coop. Ext. Publ. 142RV.
Rodríguez, P. 2000. Caracterización de cultivares de repollo (Brassica oleracea var. capitata) en la zona de Constanza. Investigación 2(1):26.

Sarita, V. 1993. Guía de producción de pepollo. Dominican Found. Agr. Dev. Santo Domingo.

Scaife, K., F. Thayer, and S. Mueller. 1998. Fresh market cabbage cultivar evaluation. Ohio Agr. Res. Dev. Ctr. Veg. Crops Branch. Ohio State Univ., Fremont. Hort. Crop Sci. Ser. 688.

Schmutterer, H. 1990. Crop pests in the Caribbean. German Intl. Agency for Dev. Press (Gesellschaft für Technische Zusammenarbeit, GTZ). Eschborn, Germany.

Schuler, T.H. and H.F. van Emdan. 2000. Resistant cabbage cultivars change the susceptibility of Plutella xylostella to Bacillus thuringiensis. Agr. Forest Entomol. 2:33-38.

Secretaría de Estado de Agricultura. 2003. Anuario Estadístico Agropecuario de la República Dominicana 2002. Secretaría de Estado de Agricultura, Santo Domingo, Dominican Republic.

Secretaría de Estado de Agricultura. 1999. Estudio de zonificación de cultivos según capacidad productiva de los suelos en República Dominicana. Secretaría de Estado de Agricultura, Santo Domingo, Dominican Republic.

Strang, J., K. Oakley, D. Lowry, D. Slone, and J. Snyder. 1999. Spring fresh market/slaw cabbage evaluation in central Kentucky, p. 23-25 In: B. Rowell (ed.). 1999 Fruit and Veg. Crops Res. Rpt. Dept. of Hort., Univ. of Kentucky PR-423.

Sundstrom, F.J. and R.N. Story. 1984. Cultivar and growing season effects on cabbage head development and weight loss during storage. HortScience 19:589-590.

Talekar, N.S. and A.M. Shelton. 1993. Biology, ecology and management of the diamondback moth. Annu. Rev. Entomol. 38:275-301.

Thomas, G.W. 1982. Exchangeable cations, p. 159-165. In: A.L. Page et al. (eds.). Methods of soil analysis: Part 2. Chemical and microbiological properties. Amer. Soc. Agron., Madison, Wis.

Torres-Mejía, R.E. 1994. Comportamiento de cultivares de repollo y evaluación de plaguicidas para el control químico de plagas del cultivo de papa en la Estación Experimental Hortícola de Constanza, República Dominicana. BS Agr. Thesis. EARTH Univ., Limón, Costa Rica.

U.S. Department of Agriculture. 2003. Vegetables 2002 summary (03). Vg 1-2. National Agr. Stat. Serv., Wash., D.C.

Workman, R.B., R.B. Chalftan, and D.J. Schuster. 1980. Management of the cabbage lopper and diamondback moth on cabbage by using two damage thresholds and live insecticide treatments. J. Econ. Entomol. 73:757-758.

Zhao, J.Z., Y.X. Li, H.L. Collins, J. Cao, E.D. Earle, and A.M. Shelton. 2001. Different crossresistance patterns in the diamondback moth (Lepidoptera: Plutellidae) resistant to Bacillus thuringiensis toxin CrylC. J. Econ. Entomol. 94(6):1547-1552. 